\title{
REVIEW
}

\section{Essential Oils and Biological Activities of the Genus Vitex (Lamiaceae) - A Review}

\author{
Fakhira Liyana Mohd Zaki and (iD) Wan Mohd Nuzul Hakimi Wan Salleh* \\ Department of Chemistry, Faculty of Science and Mathematics, Universiti Pendidikan Sultan Idris (UPSI), 35900 Tanjung \\ Malim, Perak, MALAYSIA
}

*Corresponding author. Email: wmnhakimi@fsmt.upsi.edu.my

Submitted: 28.05.2020; Accepted: 23.06.2020

\begin{abstract}
The genus Vitex which includes approximately 270 species, and is an important genus of the Lamiaceae family due to its production of secondary compounds. The plants are generally used in preventing women's complaints such as aging, menstrual, menopausal, breast disease, and infertility. The objective of this study was to carry out a review of essential oils of the genus Vitex and their biological activities. The data were collected from the scientific electronic databases including SciFinder, Scopus, Elsevier, PubMed, and Google Scholar, within miscellaneous scopes of the Vitex include either medicinal uses or essential oil studies from a different region of countries. A total of nineteen Vitex species have been reported for their essential oils and biological activities. It can be observed that the major components were caryophyllene, germacrene D, limonene, cis-calamenene, 1,8-cineole, and spathulenol. Pharmacological studies indicated that the essential oil exhibited antioxidant, antimicrobial, anti-inflammatory, antifungal, acaricidal, antibiofilm, larvicidal, cytotoxic, and acetylcholinesterase activities. This review is mainly meant to provide relevant information on the phytochemical features of Vitex species, with emphasis on the essential oil, providing guidance, or the selection of accessions or species with the best chemical profiles. Nonetheless, it seems clear that more clinical evaluations are required until essential oils can be considered as possible applications in pharmacy or as adjuvants to current medications.
\end{abstract}

Keywords: Essential oils, Vitex, Lamiaceae, caryophyllene, antimicrobial

\section{Introduction}

Essential oils are complex mixtures of volatile compounds that are produced by aromatic plants as secondary metabolites. They are responsible for the aromatic plant's properties, and for this reason, they are characterized by their strong smells (Salleh et al., 2011, 2012). In general, essential oils are liquid, volatile, and soluble in lipids and organic solvents. They can be present in all plant organs, including buds, flowers, leaves, seeds, stems, flowers, fruits, roots, wood, or bark. Different extraction techniques are widely employed for the extraction of essential oils such as steam distillation, solvent extraction, and supercritical fluid extraction (Salleh et al., 2014a, 2014b, 2014c). These essential oils are characterized by the presence of variable mixtures of bioactive compounds, mainly terpenoids, especially monoterpenes and sesquiterpenes. In contrast, the essential oils have been commercialized as a source of potential herbicides and pesticides, aromatherapy and perfumes, foods and beverages, valuable dyes, and petro crops besides being used as health care products (Salleh et al., 2015a, 2015b, 2015c). Nowadays, researchers around the world produce medicines from the essential oils of natural products such as plants. The Lamiaceae plant species have diverse biological activities in their essential oils. Within 236 genera in the Lamiaceae family, the Vitex genus has been subjected to the most abundant available studies on its ethnobotanical profiles to discover the priceless potentials.

The genus Vitex constitutes approximately 270 species generally are trees and shrubs, with woody stems about 3 meters in height (Wang \& Weller, 2006). They are widely distributed in tropical and subtropical regions such as Brazil, Nigeria, Turkey, Thailand, Vietnam, Algeria, and South Africa. Moreover, there are some species growing in the temperate zone as Iran, Montenegro, and all Europe countries (Devi and Singh, 
2014). The Vitex plant with the local name of Five-Finger and as a female herb has been used in traditional medicine and reported to have a variety of biological activities (Li et al., 2002). For instance, Vitex species broadly practiced for medicinal purposes are $V$. negundo, $V$. agnus castus, and $V$. trifolia. The leaves and seeds of $V$. negundo are extensively helpful for the treatment of rheumatism and inflammatory joint conditions (Callmander et al., 2014). The fruits of $V$. agnus castus fruits in Turkey are established in the effectiveness of women complaints such as female hormonal disorder, pre-menstrual disorder, menopausal remedy, treat aging and to improve vaginal lubrication (Ahangarpour et al., 2016). Besides, the leaves of $V$. trifolia are used to treat intestinal ailments, tuberculosis, amenorrhea, rheumatic, inflammation, sprains, wound healing, and fevers (Devi \& Singh, 2014).

Hence, the review regarding Vitex essential oils has to be done to simplify and compile the information. However, $V$. negundo, $V$. agnus castus, and $V$. trifolia essential oils have been subject to the recent review, which will not be repeated here (Khan et al., 2019; Haghighi et al., 2019; Niazi et al., 2019; Niroumand et al., 2018; Suchitra \& Cheriyan, 2018; Agalar et al., 2016; Toplan et al., 2015; Duymus et al., 2014; Rani \& Sharma, 2013). The available information about Vitex essential oils of various species was searched thoroughly via electronic search (Pubmed, SciFinder, Scopus, Google Scholar, and Web of Science) and the articles published in peer-reviewed journals were collected via library search. The review aims to compile the information regarding their medicinal uses, chemical composition, and bioactivities of the essential oils from the genus Vitex.

\section{Medicinal uses of the genus Vitex}

This review emphasizes the traditional uses and clinical potential of several Vitex species. Through this review, the authors intend to highlight the unexplored potential of the Vitex species. This genus needs to be investigated systematically so that potential species can be exploited as therapeutic agents. Various medicinal plants had been analysed by the plant researchers to match their therapeutic values and to divine the safety to human consumption. The genus Vitex is generally well-known for the treatment of female disorders, sexual dysfunctions, and inflammations. Table 1 shows the medicinal uses of several Vitex species.

Table 1. Medicinal uses of several Vitex species

\begin{tabular}{|c|c|c|}
\hline Species & Part & Medicinal uses \\
\hline V. altissima & Fruits & $\begin{array}{l}\text { To treat stomatitis, cardiac diseases, anorexia, blindness, leprosy, worm infestation } \\
\text { (Yoganarasimhan, 2000) }\end{array}$ \\
\hline V. buchananii & Leaves & To treat venereal diseases (Cabral et al., 2009) \\
\hline V. cannabifolia & Fruits & To treat analgesia, cough, used as anti-tussive (Yamasaki et al., 2008) \\
\hline V. congolensis & Leaves & To cure cicatrisation (Cabral et al., 2009) \\
\hline V. diversifolia & Barks & To cure tooth and skin diseases, headache, intestinal bilharzias (Zerbo et al., 2011) \\
\hline V. doniana & Barks & To treat gastroenteritis, diarrhea, and dysentery (Kilani, 2006) \\
\hline V. ferruginea & Leaves & To cure skin diseases, mouth sore, snake-bite (Cabral et al., 2008) \\
\hline V. gaumeri & Leaves & To treat colds, cough spelling, diarrhea, gastrointestinal affections (Damayanti et al., 1996) \\
\hline V. leucoxylon & Leaves & $\begin{array}{l}\text { To relieve headache, catarac, as a medicinal bath for fever and anemia, reduced cholesterol, anti- } \\
\text { inflammatory (Makwana et al., 1994) }\end{array}$ \\
\hline V. lucens & Leaves & $\begin{array}{l}\text { To relieve sprains, backache, treating ear ulcers, sore throats, for dead's people body wash } \\
\text { (Dykgraaf, 1992) }\end{array}$ \\
\hline V. madiensis & Leaves & To treat skin disease (Cabral et al., 2009) \\
\hline V. madiensis & Leaves & To prevent malaria (Ondo et al., 2012) \\
\hline
\end{tabular}




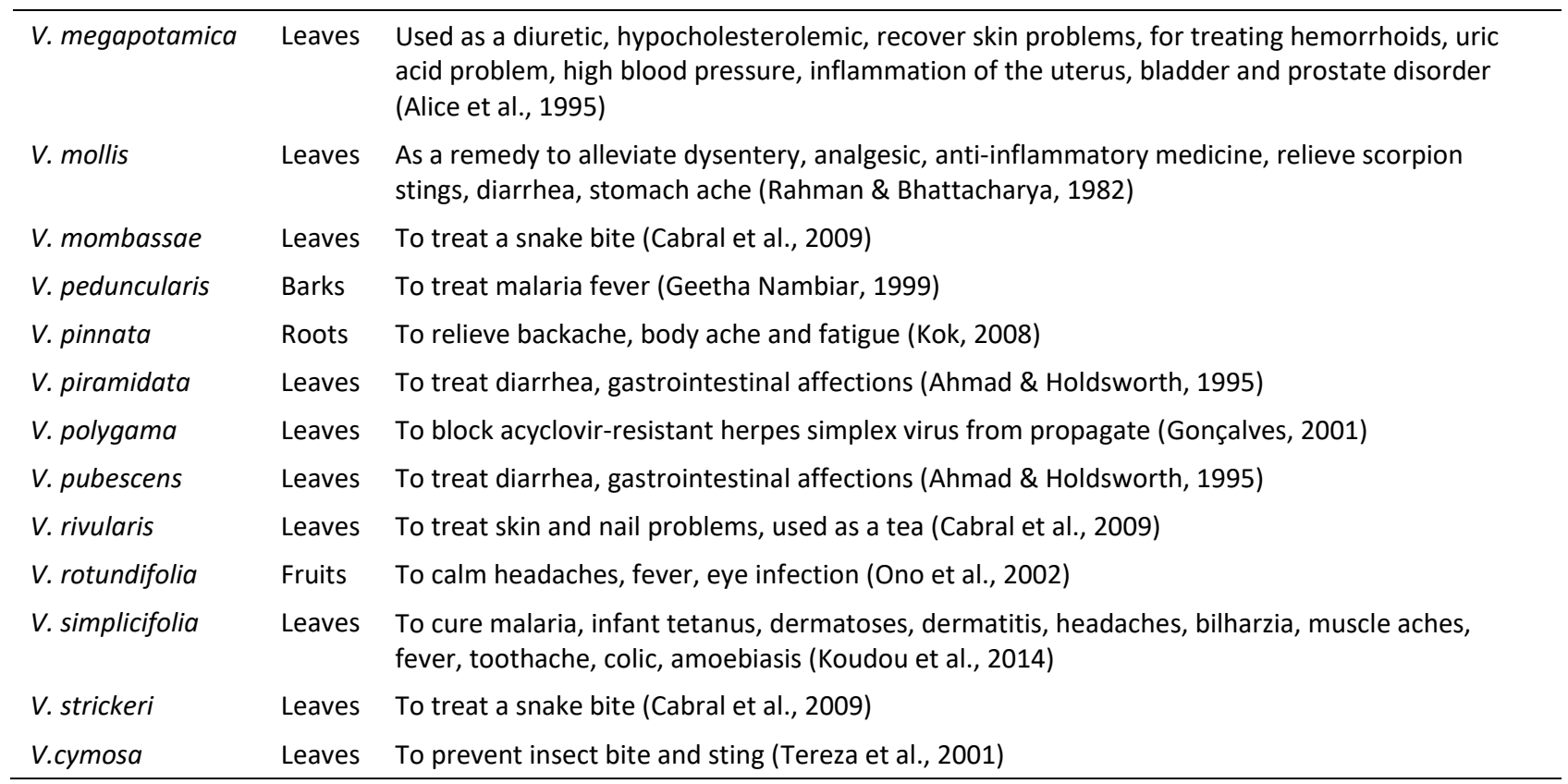

\section{Chemical Composition of Vitex Essential Oils}

Analysis of chemical components identified in Vitex essential oils shows that the oil consists of several groups of components, which are monoterpene hydrocarbons, oxygenated monoterpenes, sesquiterpene hydrocarbons, and oxygenated sesquiterpenes. Table 2 shows the major components identified in Vitex essential oils from various origins.

Table 2. Major components identified from Vitex essential oils

\begin{tabular}{|c|c|c|c|c|}
\hline Species & Country & Part & $\begin{array}{c}\text { Total } \\
\text { identified } \\
(\%)\end{array}$ & Major components \\
\hline V. capitata & Brazil & Leaves & 95.2 & $\delta$-Cadinene (7.1\%), viridiflorene (5.2\%) (De Sena Filho et al., 2017) \\
\hline V. cymosa & Brazil & Leaves & 40.96 & $\begin{array}{l}\beta \text {-Copaene- } 4-\alpha \text {-ol }(9.78 \%) \text {, caryophyllene oxide }(6.46 \%), \quad \beta \text { - } \\
\text { bisabolene }(5.16 \%) \text {, cubenol (5.09\%) (Leitao et al., 1999) }\end{array}$ \\
\hline V. diversifolia & South Africa & Leaves & 99.4 & $\begin{array}{l}\text { Limonene (74.2\%), caryophyllene oxide (3.2\%) (Ch. Nebie et al., } \\
2005)\end{array}$ \\
\hline V. doniana & Nigeria & Leaves & 92.6 & 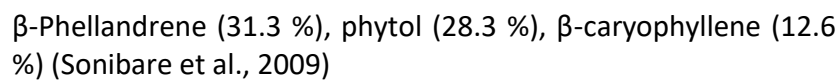 \\
\hline V. ferruginea & South Africa & $\begin{array}{l}\text { Aerial } \\
\text { parts }\end{array}$ & $83.4-90.8$ & $\begin{array}{l}\text { Germacrene D }(26.8-34.9 \%), \quad \beta \text {-phellandrene }(3.0-10.7 \%), \beta- \\
\text { caryophyllene }(4.0-6.9 \%) \text { (Cabral et al., 2008) }\end{array}$ \\
\hline \multirow[t]{4}{*}{ V. gardneriana } & Brazil & Leaves & 95.9 & $\begin{array}{l}\text { cis-Calamenene (29.7\%), 6,9-guaiadiene (14.5\%), caryophyllene } \\
\text { oxide (14.0\%) (Vale et al., 2019) }\end{array}$ \\
\hline & & & $94.71-95.20$ & $\begin{array}{l}\text { cis-Calamenene (24.45-35.62\%), 6.9-guaiadiene (12.47-28.86\%), } \\
\text { caryophyllene oxide (16.06-10.13\%) (Silva et al., 2019) }\end{array}$ \\
\hline & & & $91.4-94.7$ & $\begin{array}{l}\text { cis-Calamenene (29.7\%), 6,9-guaiadiene (14.5\%), caryophyllene } \\
\text { oxide (14.0\%) (Pereira et al. 2018) }\end{array}$ \\
\hline & Brazil & Leaves & 90.4 & $\begin{array}{l}\text { 6,9-Guaiadiene }(19.3 \%) \text {, caryophyllene oxide } \quad(18.6 \%), \text { L- } \\
\text { calamenene }(13.9 \%) \text {, (De Sena Filho et al., 2017) }\end{array}$ \\
\hline V. kwangsiensis & China & Seeds & 93.1 & $\begin{array}{l}\text { Methyl linoleate (11.2\%), caryophyllene oxide(10.3\%), } \beta \text { - } \\
\text { eudesmol (9.1\%), methyl palmitate (8.1\%) (Tian \& Liu, 2018) }\end{array}$ \\
\hline V. limonifolia & Thailand & Leaves & 97.31 & $\begin{array}{l}\text { Caryophyllene (43\%), caryophyllene oxide (13\%) (Suksamrarn et } \\
\text { al.,1990) }\end{array}$ \\
\hline
\end{tabular}




\begin{tabular}{|c|c|c|c|c|}
\hline V. megapotamica & Brazil & Leaves & 92.36 & $\begin{array}{l}\text { Butylated hydroxytoluene }(34.17 \%), \text { phytol }(12.66 \%), \alpha \text { - } \\
\text { caryophyllene }(11.84 \%), \delta \text {-elemene }(10.65 \%), \beta \text {-caryophyllene } \\
(7.82 \%) \text { (De Brum et al., 2013) }\end{array}$ \\
\hline & Brazil & Leaves & 96.8 & $\begin{array}{l}\text { (E)-Caryophyllene (16.2\%), } \quad \text {-muurolene }(13.5 \%), \alpha \text {-copaene } \\
(10.8 \%) \text { (De Sena Filho et al., 2017) }\end{array}$ \\
\hline V. obovata & South Africa & $\begin{array}{l}\text { Aerial } \\
\text { parts }\end{array}$ & 82.83 & $\begin{array}{l}\text { 1,8-Cineole (11.69\%), } \alpha \text {-copaene }(7.39 \%) \text {, caryophyllene oxide } \\
\text { (5.94\%) (Nyiligira et al., } 2004)\end{array}$ \\
\hline $\begin{array}{l}\text { V. obovate ssp. } \\
\text { wilmsii }\end{array}$ & South Africa & $\begin{array}{l}\text { Aerial } \\
\text { parts }\end{array}$ & 82.23 & a-Copaene (11.79\%), 1,8-cineole (7.18\%) (Nyiligira et al., 2004) \\
\hline V. pooara & South Africa & $\begin{array}{l}\text { Aerial } \\
\text { parts }\end{array}$ & 97.97 & $\begin{array}{l}\text { Limonene }(19.35 \%), \quad \beta \text {-selinene }(14.41 \%) \text {, cryptone }(10.05) \text {, } \\
\text { humulene epoxide II }(9.45 \%) \text {, caryophyllene oxide }(7.45 \%) \\
\text { (Nyiligira et al., 2004) }\end{array}$ \\
\hline V. polygama & Brazil & Leaves & 37.71 & $\begin{array}{l}\text { (E)-Caryophyllene (11.27\%), } \gamma \text {-elemene }(5.03 \%), \alpha \text {-pinene }(4.06 \%) \\
\text { (Leitao et al., 1999) }\end{array}$ \\
\hline V. quinata & Vietnam & Leaves & 92.1 & $\begin{array}{l}\beta \text {-Pinene }(30.1 \%), \quad \beta \text {-caryophyllene }(26.9 \%), \quad \beta \text {-elemene }(7.4 \%) \\
\text { (Dai et al., 2015) }\end{array}$ \\
\hline V. rehmannii & South Africa & $\begin{array}{l}\text { Aerial } \\
\text { parts }\end{array}$ & 80.65 & $\begin{array}{l}\text { Spathulenol (8.06\%), caryophyllene oxide }(7.93 \%) \text {, elema-1,11- } \\
\text { dien-15-ol }(5.80 \%) \text {, caryophylla-2(12),6(13)-dien-5- } \alpha \text {-ol }(5.22 \%) \\
\text { (Nyiligira et al., 2004) }\end{array}$ \\
\hline V. rivularis & Cameroon & Leaves & $88.1-90.6$ & $\begin{array}{l}\text { Germacrene } D(12.6-20.6 \%) \text {, ar-curcume }(9.1-5.5 \%), \quad \gamma \text { - } \\
\text { curcumene (7.8-9.7\%), } \beta \text {-caryophyllene }(7.3-6.6 \%) \text {, } \alpha \text {-copaene } \\
\text { (6.4-5.0\%) (Cabral et al., 2009) }\end{array}$ \\
\hline V. rontudifolia & Korea & Leaves & 70.7 & $\begin{array}{l}\alpha \text {-Pinene (13.2\%), } \alpha \text {-terpineol (10.6\%), 1,8-cineole (4.4\%), manoyl } \\
\text { oxide (4.0\%) (Kim et al., 2014) }\end{array}$ \\
\hline V. rufescens & Brazil & Leaves & 97.8 & $\begin{array}{l}\text { (E)-Caryophyllene }(21.0 \%) \text {, ledol }(15.7 \%) \text {, germacrene } D(9.3 \%), \alpha- \\
\text { humulene }(7.3 \%) \text {, allo-aromadendrene }(6.9 \%) \text {, viridiflorene } \\
(6.6 \%), \beta \text {-elemene }(5.8 \%) \text { (De Sena Filho et al., } 2017)\end{array}$ \\
\hline V. zeyheri & South Africa & $\begin{array}{l}\text { Aerial } \\
\text { parts }\end{array}$ & 82.27 & $\begin{array}{l}\text { 1,8-Cineole (15.29\%), globulol (5.46\%), linalool (5.24\%) (Nyiligira } \\
\text { et al., 2004) }\end{array}$ \\
\hline
\end{tabular}

The major components of Vitex essential oils mainly consist of sesquiterpene hydrocarbons. Caryophyllene was identified as the major component of four Vitex species which are; V. limonifolia (Thailand) (Suksamrarn al., 1990), V. polygama (Brazil) (Leitao et al., 1999), V. rufescens (Brazil), and V. megapotamica (De Sena Filho et al., 2017). Besides, germacrene D was found in two different Vitex species which are; $V$. ferruginea (South Africa) (Cabral et al., 2008) and V. rivularis (Cameroon) (Cabral et al., 2009). In addition, the other sesquiterpene hydrocarbons were $\delta$-cadinene (De Sena Filho et al., 2017), cis-calamenene (Vale et al., 2019; Silva et al., 2019; Pereira et al. 2018), 6,9-guaiadiene (De Sena Filho et al., 2017), which were found in the leaf oil of Brazillian V. capitata, V. gardneriana, and V. gardneriana, respectively. Meanwhile, spathulenol was found its richness in the oil of $V$. rehmannii (Nyiligira et al., 2004). Monoterpene hydrocarbons were also reported in Vitex essential oils. They were limonene (Ch. Nebie et al., 2005), $\beta$-phellandrene (Sonibare et al., 2009), $\alpha$-copaene (Nyiligira et al., 2004), $\beta$-pinene (Dai et al., 2015), and $\alpha$-pinene (Kim et al., 2014) which were extracted as high percentage in $V$. diversifolia, $V$. doniana, $V$. obovata wilmsii, $V$. quinata, and $V$. rontudifolia essential oils, respectively. In addition, the oxygenated monoterpenes were identified in $V$. cymosa ( $\beta$-copaene-4- $\alpha$-ol) (Leitao et al., 1999), V. obovata (1,8-cineole) (Nyiligira et al., 2004), and V. zeyheri (1,8-cineole) (Nyiligira et al., 2004) essential oils. On the other hand, another group of components that presents in Vitex essential oils were butylated hydroxytoluene and methyl linoleate, which were identified in the oils of V. megapotamica (De Brum et al., 2013) and V. kwangsiensis (Tian and Liu, 2018). It must be mentioned here that butylated hydroxytoluene is not a natural compound but an impurity. 


\section{Biological Activities of Vitex Essential Oils}

\section{Antioxidant activity}

The antioxidant activity of $V$. kwangsiensis was tested by DPPH ${ }^{\bullet}$ method and it showed weak antioxidant activity. A maximum concentration $1 \mathrm{mg} / \mathrm{mL}$ of oil was conducted and the radical scavenging activity was $26.76 \%$ (Tian \& Liu, 2018). In another study, the ferrous ion chelating activity of the $V$. gardneriana essential oil showed the best activity at $7.81 \mu \mathrm{g} / \mathrm{mL}$. Besides, the oil showed a dose-response relationship in $\beta$-carotene oxidation with the best activity at $500 \mu \mathrm{g} / \mathrm{mL}$ (Vale et al., 2019). De Brum et al., (2013) reported the $V$. megapotamica essential oil showed percentage inhibition of $35.62 \%$ and $75.25 \%$ at concentrations of 76 and $101.6 \mathrm{mg} / \mathrm{mL}$ against DPPH free-radical scavenging assay. However, this report should be read with caution since the main component in the oil is an antioxidant added to diethyl ether for protection.

\section{Antimicrobial activity}

The essential oil of $V$. gardneriana was able to inhibit the growth of S. aureus with a MIC of $0.31 \%$ v/v. However, no MIC was determined on $P$. aeruginosa. In addition, the essential oil showed about $70 \%$ to $9 \%$ and 30\% - 3\% of growth reduction on C. albicans and C. tropicalis, respectively (Vale et al., 2019). In another study, V. gardneriana essential oil gave value of $4.0 \mathrm{mg} / \mathrm{mL}$ against dermatophytes and yeasts; $C$. albicans, $C$. tropicalis, C. parapsilosis, C. krusei, and T. rubrum (Pereira et al., 2018). The V. doniana essential oil exhibited antimicrobial activity against Proteus mirabilis, Bacillus subtilis, and Candida albicans with inhibition zones of 11, 4 and $12 \mathrm{~mm}$, respectively (Sonibare et al., 2009). The essential oils of $V$. obovata ssp. obovata, V. obovata ssp. wilmsii, and $V$. zeyheri gave MIC value $8.0 \mathrm{mg} / \mathrm{mL}$ against $S$. aureus, whereas $V$. pooara and $V$. rehmannii showed MIC value 32.0 and $16.0 \mathrm{mg} / \mathrm{mL}$, respectively. In addition, $V$. zeyheri essential oil showed the best activity for $B$. cereus with MIC value $4.0 \mathrm{mg} / \mathrm{mL}$ (Nyiligira et al., 2004).

\section{Anti-inflammatory activity}

The essential oils of $V$. pooara, V. rehmannii, V. obovata ssp. obovata, V. obovata ssp. wilmsii and $V$. zeyheri reported the anti-inflammatory against 5-lipoxygenase assay with $\mathrm{IC}_{50}$ values of $25.0,40.5,42.0,48.0$, and 64.0 ppm, respectively (Nyiligira et al., 2004). The essential oil of $V$. rotundifolia suppressed LPS induced NO formation significantly in a dose-dependent fashion, by providing about $60 \%$ decrease of nitric oxide production at $25.0 \mu \mathrm{g} / \mathrm{mL}$ concentration (Kim et al., 2014).

\section{Antifungal activity}

The essential oil of $V$. ferruginea exhibited significant antifungal activity against dermatophyte strains with MIC between 0.16-0.64 $\mathrm{LL} / \mathrm{mL}$ against Epidermophyton floccosum, Trichophyton rubrum, T. mentagrophytes, Microsporum canis, and M. gypseum (Cabral et al., 2008). The essential oil of V. rivularis exhibited significant antifungal activity against dermatophyte strains ( $E$. floccosum, T. rubrum, T. mentagrophytes, M. canis, and M. gypseum) with MIC and MLC values ranging from 0.16 to $0.64 \mu \mathrm{L} / \mathrm{mL}$ and 0.32 to $2.5 \mathrm{~mL} / \mathrm{mL}$, respectively (Cabral et al., 2009).

\section{Acaricidal activity}

The toxicity against the coconut mite Aceria guerreronis showed that $V$. gardneriana essential oil had strong acaricidal activity, with an LC 50 of $0.85 \mathrm{mg} / \mathrm{mL}$. However, the essential oils of $V$. capitata, V. megapotamica, and $V$. rufescens plant did not kill adults of $A$. guerreronis over a period of $24 \mathrm{~h}$. As a way of toxicity comparison, the acaricide abamectin, sprayed at its label rate, inflicted $100 \%$ mortality to $A$. guerreronis (De Sena Filho et al., 2017). 


\section{Antibiofilm activity}

Vale et al., (2019) reported that the biomass formation of $C$. albicans and $C$. tropicalis biofilm was inhibited after $24 \mathrm{~h}$ treatment with $\mathrm{V}$. gardneriana essential oil. All concentrations tested were able to reduce $C$. albicans biomass. However, $C$. tropicalis biomass was inhibited at $2.5 \%$ to $0.312 \%$ oil concentrations. They concluded that the $V$. gardneriana essential oil reduced significantly the biofilm biomass and the number of viable cells of bacteria and yeasts, mainly on biofilm formation.

\section{Larvicidal activity}

The seasonal variation in essential oils of $V$. gardneriana was studied by Silva et al. (2019). The essential oils extracted in January $\left(\mathrm{LC}_{50} 78.3 \mu \mathrm{g} / \mathrm{mL}\right.$ ), March (LC $5044.1 \mu \mathrm{g} / \mathrm{mL}$ ), April (LC $5047.9 \mu \mathrm{g} / \mathrm{mL}$ ), May (LC 28.0 $\mu \mathrm{g} / \mathrm{mL}$ ), July ( $\mathrm{LC}_{50} 43.5 \mu \mathrm{g} / \mathrm{mL}$ ), August ( $\mathrm{LC}_{50} 62.0 \mu \mathrm{g} / \mathrm{mL}$ ), and December ( $\mathrm{LC}_{50} 84.3 \mu \mathrm{g} / \mathrm{mL}$ ) exhibited significant larvicidal activity against third instar larvae of Aedes aegypti.

\section{Cytotoxic activity}

The $V$. gardneriana essential showed that $0.3-1.25 \%$ concentrations had cytotoxic effects in 1929 cell lines, whereas no significant cytotoxic effects in HaCat cell lines was observed (Vale et al., 2019).

\section{Acetylcholinesterase activity}

The essential oil of $V$. gardneriana displayed $\mathrm{IC}_{50}$ value of $11.2 \mathrm{mg} / \mathrm{mL}$ which was assessed using a thin layer chromatographic method (Pereira et al., 2018).

\section{Conclusion}

This review compiles the medicinal uses, chemical components, and biological activities of the Vitex essential oils. The studies managed to declare that the essential oils of Vitex genus contain monoterpenes and sesquiterpenes which potentially stimulate biological activities such as antioxidant, antimicrobial, antiinflammatory, antifungal, acaricidal, antibiofilm, larvicidal, cytotoxic, and acetylcholinesterase properties. Undeniably, there are some current needs for other new plant-derived products to be tested for biological activity. The genus Vitex could be an imperative natural source for developing contemporary drugs and medicines.

\section{ACKNOWLEDGMENT}

The authors would like to thank the Department of Chemistry, Faculty of Science and Mathematics, Universiti Pendidikan Sultan Idris for research facilities.

\section{REFERENCES}

Agalar, H. G., Ciftci, G. A., Yildirim, S. U., Goger, F., Kirimer, N. (2016). The LC/ESI-MSMS profiles and biological potentials of Vitex agnus-castus extracts. Natural Product Communications, 11(11), 1655-1660.

Ahangarpour, A., Najimi, S. A., \& Farbood, Y. (2016). Effects of Vitex agnus-castus fruit on sex hormones and antioxidant indices in a d-galactose-induced aging female mouse model. Journal of the Chinese Medical Association, 79(11), 589596.

Ahmad, F. B., \& Holdsworth, D. K. (1995). Traditional medicinal plants of Sabah State Malaysia. Part III. International Journal of Pharmacognosy, 33(3), 262-264.

Alice, C. B., Mentz, L., Siqueira, N. C. S., Silva, G. A. A. B., \& Jose, K. F. (1995). Plantas Medicinais De Uso Popular: Atlas Farmacognóstico. ULBRA: Canoas, RS, Brazil. 
Cabral, C., Gonçalves, M. J., Cavaleiro, C., Salgueiro. L., Antunes, T., Sevinate-Pinto, I., \& Sales, F. (2008). Vitex ferruginea Schumach. et. Thonn. subsp. amboniensis (Gürke) Verdc.: glandular trichomes micromorphology, composition and antifungal activity of the essential oils. Journal of Essential Oil Research, 20(1), 86-90.

Cabral, C., Gonçalves, M., Cavaleiro, C., Sales, F., Boyom, F., \& Salgueiro, L. (2009). Composition and anti-fungal activity of the essential oil from Cameroonian Vitex rivularis Gürke. Natural Product Research, 23(16), 1478-1484.

Callmander, M. W., Phillipson, P. B., \& Schatz, G. E. (2014). Towards a Revision of the Genus Vitex L. (Lamiaceae) in Madagascar I: A Distinctive New Species from Northeastern Madagascar. Candollea, 69(2), 141-147.

Ch. Nebie, R. H., Yaméogo, R. T., Bélanger, A., \& Sib, F. S. (2005). Chemical composition of essential oils of Vitex diversifolia Bak. From Burkina Faso. Journal of Essential Oil Research, 17(3), 276-277.

Dai, D. N., Thang, T. D., Ogunwande, I. A., \& Lawal, O. A. (2015). Study on essential oils from the leaves of two Vietnamese plants: Jasminum subtriplinerve C.L. Blume and Vitex quinata (Lour) F.N. Williams. Natural Product Research, 30(7), 860-864.

Damayanti, M., Susheela, M., \& Sharma, G. J. (1996). Effect of plant extracts and systemic fungicide on the pineapple fruit-rotting fungus Ceratocystis Paradoxa. Cytobios, 86(346), 155-165.

De Brum, T. F., Boligon, A. A., Frohlich, J. K., Schwanz, T. G., Zadra, M., Piana, M., \& Athayde, M. I. (2013). Composition and antioxidant capacity of the essential oil of leaves of Vitex megapotamica (Sprengel) Moldenke. Natural Product Research, 27(8), 767-770.

De Sena Filho, J. G., Barreto, I. C., Soares Filho, A. O., Nogueira, P. C., Teodoro, A. V., Cruz Da Silva, A. V., Xavier, H. S., Rabbani, A. C., Spakowicz, D. J., \& Duringer, J. M. (2017). Volatile metabolomic composition of Vitex species: Chemodiversity insights and acaricidal activity. Frontiers in Plant Science, 8, 1931-1939.

Devi, W. R., \& Singh, C. B. (2014). Chemical composition, anti-dermatophytic activity, antioxidant and total phenolic content within the leaves essential oil of Vitex trifolia. International Journal of Phytocosmetics and Natural Ingredients, $1(1), 5-10$.

Duymus, H. G., Ciftci, G. A., Yildirim, U., Demirci, B., Kirimer, N. (2014). The cytotoxic activity of Vitex agnus castus L. essential oils and their biochemical mechanisms. Industrial Crops and Products, 55, 33-42.

Dykgraaf, A. C. (1992). Princely Puriri, 13. New Zealand Geography.

Geetha Nambiar, M. K. (1994). Analysis of essential oils of Vitex negundo var. negundo \& Vitex negundo var. purpurescens. Isolation, structural elucidation and biological properties of secondary metabolites in some plant. Department of Chemistry, University of Calicut.

Goncalves, J. (2001). Antiviral effect of flavonoid-rich extracts of (Verbenaceae) against acyclovir-resistant herpes simplex virus type 1. Phytomedicine, 8(6), 477-480.

Haghighi, T. M., Saharkhiz, M. J., Naddaf, F. (2019). Ontogenetic variability of Vitex pseudo-negundo essential oil and its phytotoxic activity. Scientia Horticulturae, 257, 108735.

Khan, M. F., Arora, P., \& Dhobi, M. (2019). A prospective review on phyto-pharmacological aspects of Vitex negundo Linn. Current Traditional Medicine, http://doi.org/10.2174/2215083805666191021161005

Kilani, A. M. (2006). Antibacterial assessment of whole stem bark of Vitex doniana sweet against some Enterobactriaceae. African Journal of Biotechnology, 5(10), 958-959.

Kim, C., Bu, H. J., Lee, S. J., Hyun, C.G., \& Lee, N. H. (2014). Chemical compositions and anti-inflammatory activities of essential oils from Aster spathulifolius and Vitex rotundifolia Maxim. Journal of Applied Pharmaceutical Science, 4(10), 12-15. 
Kok, R. D. (2008). The genus Vitex (Labiatae) In the Flora Malesiana Region, Excluding New Guinea. Springer Netherlands, $63,17-40$.

Koudou, J., Ouoba, A. M., Some, N., Ouedraogo, S., \& Guissou, I. P. (2014). Acute toxicity and irritancy of the essential oil of the leaves of Vitex simplicifolia Oliv. (Verbenaceae) In Burkina Faso. Journal of Pharmacology and Toxicology, 9(1), 62-67.

Leitao, S. G., Fonseca, E. N., \& dos Santos, T. C. (1999). Essential oils from two Brazilian Vitex species. Acta Horticulturae, $500,89-92$.

Li, S., Zhang, H., Qiu, S., Niu, X., Santarsiero, B. D., Mesecar, A. D., \& Sun, H. (2002). Vitexlactam a, a novel labdane diterpene lactam from the fruits of Vitex agnus-castus. Tetrahedron Letters, 43(29), 5131-5134.

Makwana, H. G., Ravishankar, B., Shukla, V. J., Bhaskarannair, R., Vijayan, N. P., Sasikala, C. K., Saraswathy, V. N., \& Bhatt, S. V. (1994). General pharmacology of Vitex leucoxylon Linn leaves. Indian Journal of Physiology and Pharmacology, 38(2), 95-100.

Niazi, A., Rahimi, V. B., Hatami, H., Shirazinia, R., Esmailzadeh-dizaji, R., Askari, N., Askari, V. R. (2019). Effective medicinal plants in the treatment of the cyclic mastalgia (breast pain): a review. Journal of Pharmacopuncture, 22(3), $131-139$.

Niroumand, M. C., Heydarpour, F., \& Farzaei, M. H. (2018). Pharmacological and therapeutic effects of Vitex agnuscastus L: A review. Pharmacognosy Reviews, 12(23), 103-114.

Nyiligira, E., Viljoen, A., Başer, K., Õzek, T., Van Vuuren, S., \& Houghton, P. (2004). Essential oil composition and in vitro antimicrobial and anti-inflammatory activity of South African Vitex species. South African Journal of Botany, 70(4), 611617.

Ondo, J. P., Lekana-Douki, J. B., Bongui, Zangedou, E. S., Zatra, R., Toure-Ndouo, F. S., \& Elomri, A. (2012). In vitro antiplasmodial activity and cytotoxicity of extracts and fractions of Vitex Madiensis, medicinal plant of Gabon. Tropical Medicine and International Health, 17(3), 316-321.

Ono, M., Yanaka, T., Yamamoto, M., Ito, Y., \& Nohara, T. (2002). New diterpenes and norditerpenes from the fruits of Vitex rotundifolia. Journal of Natural Products, 65, 357-541.

Pereira, E. J., Do Vale, J. P., Da Silva, P. T., Lima, J. D., Alves, D. R., Costa, P. S., Santos, H., Rodrigues, T. S., Menezes, J. S., Morais, S. M., Bandeira, P. N., \& Fontenelle, R. S. (2018). Circadian rhythm, and antimicrobial and anticholinesterase activities of essential oils from Vitex gardneriana. Natural Product Communications, 13(5), 635-638.

Rahman, M. S., \& Bhattacharya, G. N. (1982). Effects of leaf extract of Vitex Negundo on Lathyrus satitus Linn. used to protect stored grains from insects. Current Science, 51(8), 434-435.

Rani, A., Sharma, A. (2013). The genus Vitex: A review. Pharmacognosy Reviews, 7(14), 188-198.

Salleh, W. M. N. H. W., Ahmad, F., Khong, H. Y., \& Sirat, H. M. (2011). Chemical compositions, antioxidant and antimicrobial activities of the essential oils of Piper caninum Blume. International Journal of Molecular Sciences, 12(11), 7720-7731.

Salleh, W. M. N. H. W., Ahmad, F., Khong, H. Y., \& Sirat, H. M. (2012). Chemical compositions, antioxidant and antimicrobial activities of the essential oils of Piper officinarum C.DC (Piperaceae). Natural Product Communications, 7(12), 1659-1662.

Salleh, W. M. N. H. W., Ahmad, F., \& Khong, H. Y. (2014a). Chemical composition and antimicrobial activity of essential oil of Piper muricatum Blume (Piperaceae). Journal of Essential Oil Bearing Plants, 17(6), 1329-1334.

Salleh, W. M. N. H. W., Ahmad, F., \& Khong, H. Y. (2014b). Chemical compositions and antimicrobial activity of the essential oils of Piper abbreviatum, P. erecticaule and P. lanatum (Piperaceae). Natural Product Communications, 9(12), 1795-1798. 
Salleh, W. M. N. H. W., Ahmad, F., \& Khong, H. Y. (2014c). Chemical composition of Piper stylosum Miq. and Piper ribesioides Wall. essential oils and their antioxidant, antimicrobial and tyrosinase inhibition activities. Latin American and Caribbean Bulletin of Medicinal and Aromatic Plants, 13(5), 488-497.

Salleh, W. M. N. H. W., Ahmad, F., Khong, H. Y., \& Zulkifli, R. M. (2015a). Chemical compositions and biological activities of essential oils of Beilschmiedia glabra. Natural Product Communications, 10(7), 1297-1300.

Salleh, W. M. N. H. W., Ahmad, F., \& Khong, H. Y. (2015b). Chemical compositions and biological activities of the essential oils of Beilschmiedia madang Blume (Lauraceae). Archives of Pharmacal Research, 38, 485-493.

Salleh, W. M. N. H. W., Ahmad, F., \& Khong, H. Y. (2015c). Antioxidant and anticholinesterase activities of essential oils of Cinnamomum griffithii and C. macrocarpum. Natural Product Communications, 10(8), 1465-1468.

Silva, P., Santos, H., Teixeira, A., Bandeira, P., Holanda, C., Vale, J., \& Santiago, G. (2019). Seasonal variation in the chemical composition and larvicidal activity against Aedes aegypti of essential oils from Vitex gardneriana Schauer. South African Journal of Botany, 124, 329-332.

Sonibare, O. O., Effiong, I., Oladosu, I., \& Ekundayo, O. (2009). Chemical constituents and antimicrobial activity of the essential oil of Vitex doniana sweet (Verbernaceae). Journal of Essential Oil Research, 12(2), 185-188.

Suchitra, M., \& Cheriyan, B.V. (2018). Vitex trifolia: An ethnobotanical and pharmacological review. Asian Journal of Pharmaceutical and Clinical Research, 11(4), 12-14.

Suksamrarn, A., Aphaijitt S., Brophy, J. J. (1990). The volatile leaf oil of Vitex limonifolia Wall. Flavour and Fragrance Journal, 5(1), 53-55.

Tereza, C. S., Jan, S., Franco, D. M., \& Suzana, G. (2001). Iridoids from Vitex cymosa. Journal of the Brazilian Chemical Society, 12(6), 763-766.

Tian, Z., \& Liu, X. (2018). Chemical composition and antioxidant activity of the seeds oil of Vitex kwangsiensis C. Pei. Records of Natural Products, 12(6), 630-633.

Toplan, G. G., Kurkcuoglu, M., Baser, K. H. C., Sariyar, G. (2015). Composition of the essential oils from samples of Vitex agnus-castus L. growing in Turkey. Journal of Essential Oil Research, 27(4), 337-342.

Vale, J. P., Ribeiro, L. H., Vasconcelos, M. A., Sá-Firmino, N. C., Pereira, A. I., Nascimento, M. F., \& Teixeira, E. H. (2019). Chemical composition, antioxidant, antimicrobial and antibiofilm activities of Vitex gardneriana Schauer leaves' essential oil. Microbial Pathogenesis, 135, 103608.

Wang, L., \& Weller, C.L. (2006). Recent advances in extraction of nutraceuticals from plants. Trends in Food Science \& Technology, 17(6), 300-312.

Yamasaki, T., Kawabata, T., Masuoka, C., Kinjo, J., Ikeda, T., Nohara, T., \& Ono, M. (2008). Two new lignin glucosides from the fruit of Vitex cannabifolia. Journal of Natural Medicines, 62, 47-51.

Yoganarasimhan, S. N. (2000). Medicinal Plants of India: Tami Nadu. Cyber Media, Bangalore.

Zerbo, P., Millogo Rasolodimby, J., Nacoulma Ouedraogo, O., \& Van Damme, P. (2011). Plantes médicinales et pratiques médicales AU Burkina Faso: Cas des Sanan. Bois \& Forets Des Tropiques, 307, 41. 